\title{
ANALISIS POTENSI SUMBERDAYA PETERNAK UNTUK PENGEMBANGAN INTEGRASI SAPI POTONG DAN TANAMAN PANGAN
}

\author{
The Potential of Farmers Resources for Development in Integration \\ of Beef Cattle and Crops
}

\author{
Agustina Abdullah \\ Jurusan Sosial Ekonomi Peternakan Fakultas Peternakan Universitas Hasanuddin \\ Jalan Perintis Kemerdekaan KM 10 Kampus UNHAS Tamalanrea Makassar \\ Email : abdullah_ina@yahoo.com
}

\begin{abstract}
This study aims to analyze the potential of livestock and crop in supporting the integration of development prospects for beef cattle and crops. Data were collected regarding the characteristics of farmers, and livestock characteristics were analyzed descriptively. To analyze the potential resources of farmers are resource potential crop waste and animal waste, an analysis of the estimated carrying capacity of waste production and food crops, and production and the carrying capacity of livestock waste as a source of fertilizer. The results showed that the total crops residues as feed for beef cattle at 222.54 ton of dry matter and carrying capacity as feed as much as 97.61 livestock unit $(L U)$. On the other hand, the production of feces produced from cattle as much as 43 ST, obtained estimates of the number of 141.26 tons of feces, and when done processing feces into compost can be produced fertilizers as much as 79.10 ton.
\end{abstract}

Keywords: Beef cattle, crops, farmers, integration

\begin{abstract}
ABSTRAK
Penelitian ini bertujuan untuk menganalisis potensi sumberdaya yang dimiliki peternak yaitu sumberdaya ternak dan tanaman pangan dalam mendukung prospek pengembangan integrasi sapi potong dan tanaman pangan di pedesaan. Data yang dikumpulkan terkait dengan karakteristik peternak, karakteristik kepemilikan ternak dianalisis secara deskriptif. Untuk menganalisis potensi sumberdaya peternak yaitu potensi sumberdaya limbah tanaman pangan dan limbah ternak, dilakukan analisis estimasi produksi dan daya dukung limbah tanaman pangan, dan produksi dan daya dukung limbah ternak sebagai sumber pupuk. Hasil penelitian menunjukkan bahwa total produksi limbah tanaman pangan sebagai sumber pakan sapi potong sebesar 222,54 ton bahan kering, dengan distribusi jerami padi 102,17 ton bahan kering, dan selebihnya adalah jerami jagung. Dengan jumlah produksi limbah tanaman pangan tersebut, memiliki potensi daya dukung sebagai pakan ternak untuk sebanyak 97,61 satuan ternak (ST). Dilain pihak, produksi feses yang dihasilkan dari ternak sapi sebanyak 43 ST, diperoleh estimasi jumlah feses sebesar 141,26 ton, dan jika dilakukan pengolahan feses menjadi pupuk kompos (kandang) dapat dihasilkan pupuk sebanyak 79,10 ton.
\end{abstract}

Kata kunci : Sapi potong, tanaman pangan, sumberdaya peternak, integrasi

\section{PENDAHULUAN}

Sumber daya usaha pertanian/peternakan terutama tanaman pangan dan ternak merupakan komoditas ekonomi yang potensial untuk dikembangkan. Basuni et al. (2010) melaporkan bahwa tanaman pangan dan ternak merupakan komoditas unggulan karena berpotensi meningkatkan pertumbuhan ekonomi pedesaan. Potensi dari komoditi tersebut 
ditandai dengan terus meningkatnya permintaan dari konsumen. Pengembangan usaha tani/ternak di wilayah pedesaan memiliki banyak kendala.

Salah satu kendala utama di bidang pertanian adalah mahalnya harga pupuk sedangkan di bidang peternakan adalah kurangnya ketersedian pakan untuk memenuhi kebutuhan ternak. Model pengembangan yang tepat untuk masalah tersebut adalah integrasi tanaman pangan dengan ternak. Sistem Integrasi Tanaman-Ternak (SITT) dalam sistem usaha pertanian di suatu wilayah merupakan ilmu rancang bangun dan rekayasa sumber daya pertanian yang tuntas. SITT pada dasarnya tidak terlepas dari kaidah-kaidah ilmu usaha tani yang berkembang lebih lanjut. Ilmu usaha tani itu sendiri merupakan suatu proses produksi biologis yang memanfaatkan sumber daya alam, sumber daya manusia, modal, dan manajemen yang jumlahnya terbatas (Kusnadi, 2008).

Gunarwan dan Sulastiya (2010) menjelaskan bahwa integrasi adalah adanya sinergi dari usaha yang diintegrasikan, dengan tujuan tanaman dan ternak dalam hal ini mampu memanfaatkan produk ikutan dari masing-masing komoditi untuk saling melengkapi. Pengembangan sistem integrasi tanaman ternak (sapi) bertujuan untuk : 1) mendukung upaya peningkatan kandungan bahan organik lahan pertanian melalui penyediaan pupuk organik yang memadai, 2) mendukung upaya peningkatan produktivitas tanaman, 3) mendukung upaya peningkatan produksi daging dan populasi ternak sapi, dan 4) meningkatkan pendapatan petani atau pelaku pertanian (Suryana, 2009).

Menurut Kariyasa dan Kasryno (2004), usaha ternak sapi akan efisien jika manajemen pemeliharaan diintegrasikan dengan tanaman sebagai sumber pakan bagi ternak itu sendiri. Ternak sapi menghasilkan pupuk untuk meningkatkan produksi tanaman, sedangkan tanaman dapat menyediakan pakan hijauan bagi ternak. Untuk itu, penelitian ini bertujuan untuk menganalisis potensi sumberdaya yang dimiliki peternak yang mencakup sumberdaya ternak dan tanaman pangan dalam mendukung prospek pengembangan integrasi sapi potong dan tanaman pangan di pedesaan.

\section{BAHAN DAN METODE PENELITIAN}

Penelitian dilaksanakan di Kelompok Tani Budidaya Ternak Kecamatan Mattirosompe Kabupaten Pinrang. Lokasi penelitian dilakukan secara sengaja (purposive) dengan pertimbangan bahwa anggota kelompok tani tersebut sebanyak 16 orang, melakukan usaha tani tanaman pangan yaitu padi sawah dan jagung, dan pemeliharaan sapi potong. Penelitian dilakukan dengan metode survey menggunakan kuesioner untuk mengetahui 
potensi sumberdaya yang dimiliki oleh peternak yaitu ternak sapi potong dan limbahnya, serta sumberdaya pakan berupa hijauan limbah tanaman pangan.

Data yang dikumpulkan diperoleh dengan melakukan survey dan wawancara langsung kepada peternak menggunakan kuesioner. Data yang diperoleh terkait dengan karakteristik peternak dan karakteristik kepemilikan ternak dianalisis secara deskriptif. Untuk menganalisis potensi sumberdaya peternak yaitu potensi sumberdaya limbah tanaman pangan sebagai sumber pakan, dan sumberdaya limbah ternak sebagai sumber pupuk, dilakukan analisis dengan pendekatan pada parameter.

\section{Paramater Penelitian}

a. Produksi bahan kering (BK) limbah tanaman pangan

Produksi bahan kering (BK) limbah tanaman pangan (ton/tahun) dihitung dengan menggunakan rumus:

\section{Produksi bahan kering = Luas tanam $($ ha $) \times$ produksi limbah BK(ton $/$ ha $)$}

Standar produksi BK limbah tanaman pangan berbeda untuk setiap jenis tanaman. Syamsu (2006) melaporkan bahwa tanaman padi menghasilkan jerami padi 5.94 ton bahan kering/ha, tanaman jagung menghasilkan jerami jagung 6 ton bahan kering/ha.

b. Daya dukung limbah tanaman pangan

Daya dukung pakan bahan kering untuk ternak (ST) dihitung dengan menggunkan rumus:

$$
\text { Daya dukung limbah tanaman }(\text { ST })=\frac{\text { Total produksi BK }(\text { ton })}{\text { Kebutuhan BK 1 ST (ton/tahun) }}
$$

c. Produksi Feses Sapi Potong

Produksi feses (ton/tahun) dihitung dengan menggunakan rumus :

$$
\text { Produksi feses }=\frac{\text { Jumlah ternak (ST) } x \text { Produksi feses }(\mathrm{kg} / \mathrm{hari}) \times 365}{1000}
$$

Produksi feses ternak sapi dewasa (1 ST) adalah 9 kg/hari (Kasworo et al., 2013).

\section{d. Produksi pupuk kompos}

Produksi pupuk kompos (ton/tahun) dihitung dengan menggunakan rumus :

Produksi kompos = Total produksi Feses (kg) x konversi feses ke kompos (\%)

Konversi feses menjadi pupuk kompos adalah 56\% atau $1 \mathrm{~kg}$ feses segar menghasilkan $0.56 \mathrm{~kg}$ pupuk kompos (Kasworo et al., 2013). 
e. Daya dukung limbah ternak sebagai pupuk kompos

Daya dukung limbah ternak sapi potong (pupuk kompos) untuk tanaman pangan (ha) dihitung dengan menggunakan rumus:

$$
\text { Daya dukung pupuk kompos }(\mathrm{ha})=\frac{\text { Total produksi pupuk kompos (ton) }}{\text { Kebutuhan pupuk kompos untuk tanaman pangan (ton/ha) }}
$$

\section{HASIL DAN PEMBAHASAN}

\section{Karakteristik Peternak Responden}

Berdasarkan hasil survey yang dilakukan terhadap peternak anggota Kelompok Tani Budidaya Ternak diperoleh deskripsi karakteristik peternak, seperti terlihat pada Tabel 1. Sebanyak 75\% peternak responden (anggota kelompok) berumur 31-40 tahun. Menurut Nurhasikin (2013) bahwa manusia dikatakan usia produktif, ketika penduduk berusia pada rentang 15-64 tahun. Tingkat pendidikan peternak adalah tamat SLTP (56,3\%) dan SLTA $(43,7 \%)$. Secara umum dapat dijelaskan bahwa dengan tingkat pendidikan SLTP dan SLTA memberikan indikasi bahwa peternak akan lebih mudah untuk menerima berbagai hal-hal yang baru misalnya teknologi.

Rata-rata jumlah anggota keluarga sebanyak 3-6 orang (81,2\%), dengan kirasan pendapatn keluarga diatas Rp.1.000.000 hingga Rp.1.500.000. Rendahnya penghasilan per bulan karena seluruh responden hanya menggantungkan diri dengan beternak dan bertani. Apabila peternak mampu memanfaatkan kotoran sapi sebagai pupuk kompos maupun pemanfaatan teknologi secara efektif dan efisien maka pendapatan yang diperoleh tentunya dapat ditingkatkan.

Kisaran jumlah kepemilikan ternak sebagian besar diatas 3 ekor hingga 8 ekor per responden, dengan luas kepemilikan lahan sebagian besar lebih 0.5 hingga 1.5 ha per responden. Untuk pengalaman beternak, responden sebagian kurang dari 5 tahun dan selebihnya di atas 5 tahun, dengan pengalaman berusahatani sebesar 93,7\% diatas 5 tahun. Hal ini menunjukkan bahwa responden telah lama menggeluti usahatani tanaman pangan (padi dan jagung) dibanding beternak sapi potong.

\section{Karakteristik Kepemilikan Ternak}

Jumlah populasi ternak sapi potong yang dimiliki oleh anggota kelompok tani Budidaya Ternak adalah 63 ekor atau 43 satuan ternak (ST), struktur populasi ternak sapi potong jantan sebesar 50,8\% dan betina 49,2\%. Jika kepemilikan ternak ditinjau dari struktur 
umur ternak, Tabel 2 menunjukkan bahwa sapi potong dengan umur muda ( $<1$ tahun) sebanyak 12 ekor (19,0\%), umur muda (1-2 tahun) sebanyak 22 ekor (34,9\%), serta umur dewasa ( $>2$ tahun) sebesar 46,0\% atau 29 ekor.

Tabel 1. Karakteristik Peternak Responden

\begin{tabular}{|c|c|c|c|}
\hline No & Uraian & $\begin{array}{l}\text { Jumlah Responden } \\
\text { (orang) }\end{array}$ & $\begin{array}{l}\text { Persentase } \\
\quad(\%)\end{array}$ \\
\hline \multirow[t]{3}{*}{1} & Umur peternak (tahun) & & \\
\hline & $31-40$ & 12 & 75,0 \\
\hline & $41-50$ & 4 & 25,0 \\
\hline \multirow[t]{3}{*}{2} & Pendidikan & & \\
\hline & Tamat SLTP & 9 & 56,3 \\
\hline & Tamat SLTA & 7 & 43,7 \\
\hline \multirow[t]{4}{*}{3} & Jumlah keluarga (jiwa) & & \\
\hline & $<3$ & 3 & 18,8 \\
\hline & $3-4$ & 7 & 43,8 \\
\hline & $5-6$ & 6 & 37,4 \\
\hline \multirow[t]{3}{*}{4} & Pendapatan (Rp / Bulan) & & \\
\hline & $\leq 1.000 .000$ & 5 & 31,3 \\
\hline & $>1.000 .000-1.500 .000$ & 11 & 68,7 \\
\hline \multirow[t]{3}{*}{5} & Kepemilikan ternak sapi (ekor) & & \\
\hline & $<3$ & 4 & 25,0 \\
\hline & $>3$ & 12 & 75,0 \\
\hline \multirow[t]{4}{*}{6} & Kepemilikan lahan (ha) & & \\
\hline & $\leq 0.5$ & 4 & 25,0 \\
\hline & $>0.5-1.5$ & 9 & 56,3 \\
\hline & $>1.5-2.5$ & 3 & 18,7 \\
\hline \multirow[t]{4}{*}{7} & Pengalaman beternak sapi (tahun) & & \\
\hline & $\leq 5$ & 8 & 50,0 \\
\hline & $>5-10$ & 7 & 43,8 \\
\hline & $>10-15$ & 1 & 6,2 \\
\hline \multirow[t]{4}{*}{8} & Pengalaman bertani (tahun) & & \\
\hline & $\leq 5$ & 1 & 6,3 \\
\hline & $>5-10$ & 8 & 50,0 \\
\hline & $>10-15$ & 7 & 43,7 \\
\hline
\end{tabular}

Jumlah ternak anak dan muda jauh lebih sedikit daripada yang dewasa dikarenakan rata-rata para peternak lebih sering menjual ternak anak untuk menutupi biaya hidup serta biaya pendidikan anak-anak mereka sedangkan ternak dewasa tetap dipertahankan sebagai 
simpanan masa depan. Ternak sapi potong yang dimiliki oleh kelompok tani memiliki potensi limbah ternak berupa feses sebagai bahan baku utama diolah menjadi pupuk kompos. Oleh sebab itu dengan memaksimalkan berbagai potensi yang ada integrasi ternak tanaman pangan dapat dijalankan lebih baik.

Tabel 2. Karakteristik Kepemilikan Ternak Sapi Potong

\begin{tabular}{|c|c|c|c|c|}
\hline \multirow[t]{2}{*}{ No } & \multirow{2}{*}{$\begin{array}{l}\text { Jumlah kepemilikan ternak } \\
\text { berdasarkan umur ternak }\end{array}$} & \multicolumn{3}{|c|}{$\begin{array}{l}\text { Jumlah kepemilikan ternak berdasarkan jenis } \\
\text { kelamin }\end{array}$} \\
\hline & & Jantan & Betina & Total \\
\hline \multirow[t]{5}{*}{1} & Jumlah ternak (ekor) & & & \\
\hline & Anak & $9 \quad(75,0 \%)$ & $3 \quad(25,0 \%)$ & $12(19,0 \%)$ \\
\hline & Muda & $10 \quad(45,5 \%)$ & $12 \quad(54,5 \%)$ & $22(34,9 \%)$ \\
\hline & Dewasa & $13 \quad(44,8 \%)$ & $16 \quad(55,2 \%)$ & $29 \quad(46,0 \%)$ \\
\hline & Jumlah & $32 \quad(50,8 \%)$ & $31 \quad(49,2 \%)$ & 63 \\
\hline \multirow[t]{5}{*}{2} & Jumlah ternak (ST) & & & \\
\hline & Anak & 2,25 & 0,75 & 3,00 \\
\hline & Muda & 5,00 & 6,00 & 11,00 \\
\hline & Dewasa & 13,00 & 16,00 & 29,00 \\
\hline & Jumlah & 20,25 & 22,75 & 43,00 \\
\hline
\end{tabular}

Keterangan : ST, satuan ternak

\section{Estimasi Produksi dan Daya Dukung Limbah Tanaman Pangan}

Jumlah produksi limbah tanaman pangan merupakan salah faktor yang berperan dalam mengestimasi potensi yang dimiliki oleh peternak untuk melakukan suatu integrasi ternak sapi potong dan tanaman pangan, terutama apabila ditinjau dari aspek daya dukungnya sebaga pakan ternak. Berdasarkan hasil wawancara, diketahui bahwa dari 16 orang anggota kelompok tani Budidaya Ternak, terdapat 9 orang peternak yang melakukan usaha tani tanaman pangan dengan pola tanam dua kali dalam setahun yaitu pola tanam pertama adalah padi, dan pola tanam kedua adalah jagung. Selebihnya, sebanyak 7 orang hanya menanam padi saja dalam setahun.

Berdasarkan pola tanam tersebut di atas, dilakukan analisis estimasi potensi produksi dan daya dukung limbah tanaman pangan sebagai sumber pakan sapi potong. Estimasi dilakukan untuk mengetahui seberapa besar sumberdaya yang dimiliki oleh peternak (kelompok tani) dalam mendukung penyediaan pakan bagi sapi potong jika dilakukan penerapan integrasi sapi potong dan tanaman pangan. Jumlah produksi produksi dan daya 
dukung limbah tanaman pangan sebagai sumber pakan sapi potong, yang dimiliki oleh kelompok tani Budidaya Ternak, seperti terlihat pada Tabel 3.

Tabel 3. Estimasi Produksi dan Daya Dukung Limbah Tanaman Pangan sebagai Sumber Pakan Sapi Potong

\begin{tabular}{lcccc}
\hline Uraian & Jerami Padi & \multicolumn{2}{c}{ Jerami Jagung } & Total \\
\hline $\begin{array}{l}\text { Produksi bahan } \\
\text { kering (ton) }\end{array}$ & $102,17 \quad(\mathrm{n}=16)$ & $120,38 \quad(\mathrm{n}=9)$ & 222,54 \\
\hline $\begin{array}{l}\text { Daya dukung } \\
\text { sebagai pakan (ST) }\end{array}$ & 44,81 & 52,80 & 97,61 \\
\hline
\end{tabular}

Keterangan $=\mathrm{n}$, adalah jumlah peternak responden

Tabel 3 menunjukkan bahwa, total produksi limbah tanaman pangan sebagai sumber pakan sapi potong sebesar 222,54 ton bahan kering, dengan distribusi jerami padi 102,17 ton bahan kering, dan selebihnya adalah jerami jagung. Dengan jumlah produksi limbah tanaman pangan tersebut, memiliki potensi daya dukung sebagai pakan ternak untuk sebanyak 97,61 satuan ternak (ST). Berdasarkan populasi ternak sapi potong yang dimiliki oleh anggota kelompok yaitu 43 ST (Tabel 2) dan dilain pihak daya dukung limbah tanaman pangan sebesar 97,61 ST, maka dapat dinyatakan bahwa potensi daya dukung limbah tanaman pangan yang dimiliki oleh peternak melebihi dari jumlah populasi ternaknya (43 ST). Dengan demikian, peternak memiliki potensi sumberdaya yang lebih dari cukup untuk memenuhi kebutuhan pakan bagi ternak sapinya.

\section{Estimasi Produksi dan Daya Dukung Limbah Ternak Sapi Potong}

Jumlah produksi limbah ternak merupakan faktor pendukung untuk mengestimasi potensi sumberdaya yang dimiliki oleh peternak untuk melakukan suatu integrasi sapi potong dan tanaman pangan, terutama apabila ditinjau dari aspek daya dukungnya sebagai pupuk untuk lahan pertanian. Berdasarkan hasil analisis produksi feses yang dihasilkan dari ternak sapi yang dimiliki oleh anggota Kelompok Tani Budidaya Ternak sebanyak 43 ST, diperoleh estimasi jumlah feses sebesar 141,26 ton, dan jika dilakukan pengolahan feses menjadi pupuk kompos (kandang) dapat dihasilkan pupuk sebanyak 79,10 ton (Tabel 4).

Dengan demikian, jumlah pupuk kompos yang dihasilkan tersebut memiliki daya dukung atau dapat digunakan untuk memupuk tanaman padi dan jagung yang diusahakan oleh peternak responden seluas 19,78 ha. Jika dibandingkan jumlah luas tanam padi dan 
jagung sebesar 35,6 ha, maka jumlah pupuk yang dihasilkan tersebut masih kurang/rendah dari kebutuhan.

Tabel 4. Estimasi Produksi dan Daya Dukung Limbah Ternak (Feses) sebagai Sumber Pupuk Kandang/kompos

\begin{tabular}{ll}
\hline Uraian & Jumlah \\
\hline Produksi feses (ton) & 141,26 \\
Produksi pupuk kandang (ton) & 79,10 \\
Daya dukung pupuk (ha) & 19,78 \\
\hline
\end{tabular}

\section{Prospek Integrasi Sapi Potong dan Tanaman Pangan}

Prospek pengembangan model integrasi ternak sapi dan tanaman pangan di Kelompok Tani Budidaya Ternak dapat diketahui dengan mengindentifikasi peternak yang mempunyai daya dukung pakan yang mencukupi kebutuhan ternak, dan pupuk yang mencukupi untuk kebutuhan lahan tanaman pangan. Dalam rangka pengembangan integrasi sapi potong dan tanaman pangan di tingkat peternak responden memiliki empat karakteristik yang berbeda ditinjau dari kecukupan pakan untuk ternak sapid an kecukupan pupuk untuk tanaman pangan.

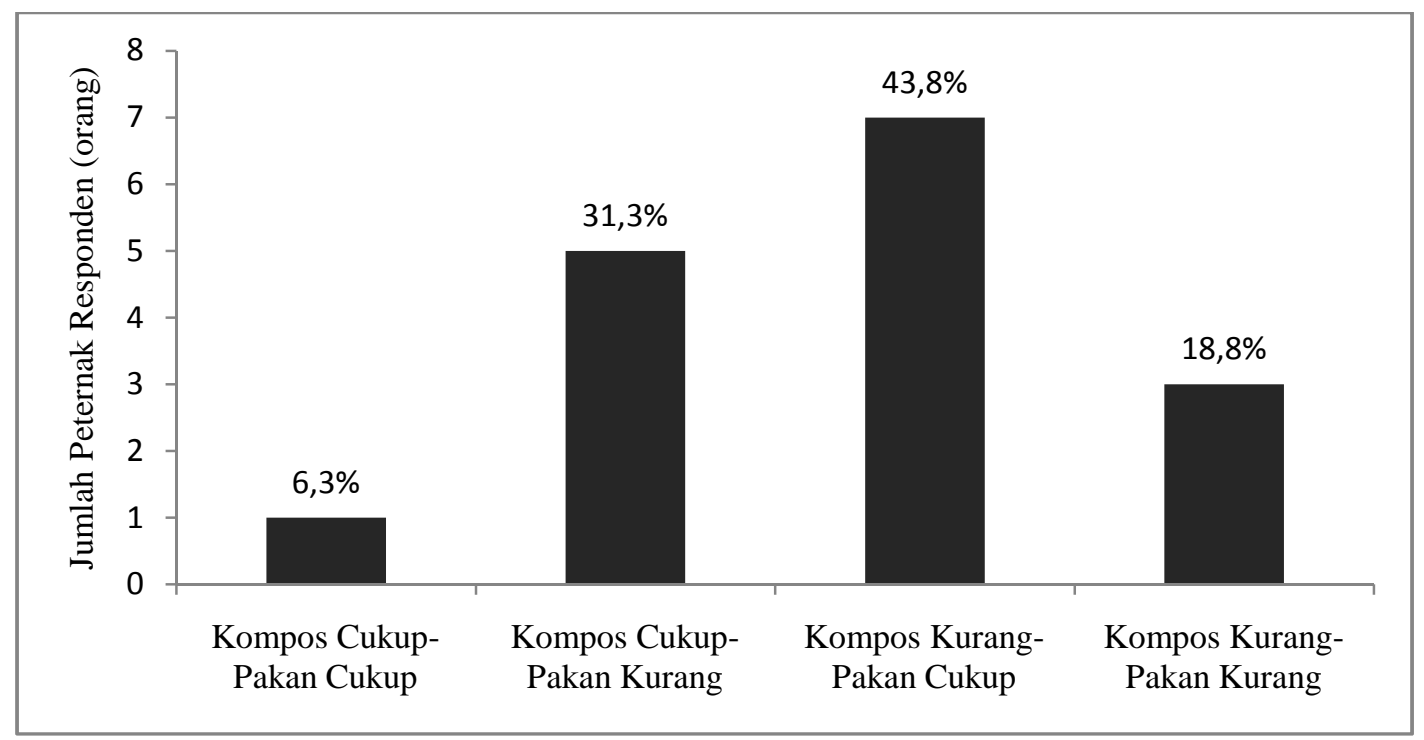

Gambar 1. Potensi Integrasi Sapi Potong dan Tanaman Pangan

Gambar 1 menunjukkan bahwa, terdapat satu orang peternak responden yang mampu memenuhi kebutuhan pakan untuk ternak sapi dan pupuk untuk tanaman pangan, dan lima 
orang peternak yang mencukupi kebutuhan pupuk namun ketersediaan atau daya dukung pakan dari limbah tanaman pangan tidak mencukupi untuk kebutuhan ternak sapi yang dimilikinya. Dilain pihak, terdapat tujuh orang peternak responden yang memiliki pakan yang cukup namun pupuk yang dimiliki tidak dapat memenuhi kebutuhan untuk pemupukan tanaman pangan. Dengan demikian, dapat pula dinyatakan bahwa dari seluruh peternak responden anggota kelompok tani sebanyak 31,25 \% memiliki potensi pupuk kompos yang dihasilkan dari limbah ternaknya untuk digunakan sebagai sumber hara bagi tanaman pangan yaitu padi dan jagung. Sebaliknya, terdapat $50 \%$ peternak responden dapat memenuhi kebutuhan pakan bagi ternak sapi.

Untuk menerapkan model integrasi kepada semua peternak responden, maka peternak yang kekurangan sumber daya pakan diharapkan mencari alternatif sumber daya yang lain seperti limbah pertanian lainnya, ataupun melakukan penanaman hijauan pakan. Bagi peternak yang kekurangan pupuk harus meningkatkan jumlah kepemilikan ternak sapi untuk meningkatkan jumlah pupuk kompos dari feses atau dengan memanfaatkan urine dari ternak sebagai pupuk cair untuk menutupi kekurangan dari pupuk kompos. Priyanti, et al (2008), menyatakan bahwa masalah kesuburan lahan karena terbatasnya kandungan bahan organik tanah dan pengembangan usaha peternakan sapi, dapat diatasi secara simultan dengan menerapkan pola integrasi tanaman dan ternak melalui pendekatan low external input. Pola integrasi ini merupakan penerapan usaha terpadu antara komoditi tanaman, dalam hal ini padi dan jagung, dan komoditi peternakan (sapi potong), yang dengan pola itu jerami padi digunakan sebagai pakan sapi, sedangkan kotoran ternak sebagai bahan utama pembuatan kompos dimanfaatkan untuk pupuk organik yang dapat meningkatkan kesuburan lahan.

\section{KESIMPULAN}

Potensi sumberdaya yang dimiliki oleh peternak dapat diestimasi bahwa produksi limbah tanaman pangan sebagai sumber pakan sapi potong sebesar 222,54 ton bahan kering, dengan distribusi jerami padi 102,17 ton bahan kering, dan selebihnya adalah jerami jagung. Dengan jumlah produksi limbah tanaman pangan tersebut, memiliki potensi daya dukung sebagai pakan ternak untuk sebanyak 97,61 satuan ternak (ST). Dilain pihak, produksi feses yang dihasilkan dari ternak sapi yang dimiliki oleh anggota Kelompok Tani Budidaya Ternak sebanyak 43 ST, diperoleh estimasi jumlah feses sebesar 141,26 ton, dan jika dilakukan pengolahan feses menjadi pupuk kompos (kandang) dapat dihasilkan pupuk sebanyak 79,10 ton. Terdapat 31,25\% peternak responden anggota kelompok tani memiliki potensi pupuk 
kompos yang dihasilkan dari limbah ternaknya untuk digunakan sebagai sumber hara bagi tanaman pangan yaitu padi dan jagung. Sebaliknya, terdapat $50 \%$ peternak responden dapat memenuhi kebutuhan pakan bagi ternak sapi.

\section{UCAPAN TERIMA KASIH}

Penulis mengucapkan terima kasih kepada Direktorat Jenderal Pendidikan Tinggi Kementerian Pendidikan dan Kebudayaan, dan Lembaga Penelitian dan Pengabdian Masyarakat Universitas Hasanuddin atas bantuan biaya penelitian melalui Hibah Penelitian Unggulan Perguruan Tinggi Tahun 2014.

\section{DAFTAR PUSTAKA}

Basuni, R., Muladno, C. Kusmana, Suryahadi. 2010. Sistem Integrasi Padi-Sapi Potong di Lahan Sawah. Iptek Tanaman Pangan Vol. 5 (1) : 31-48

Gunarwan., A. Sulastiya. 2010. Pengembanga Usaha Peternakan Sapi Melalui Pola integrasi Tanaman Ternak Dan Pembangunan Kawasan Peternakan. Jurnal Ilmu Ilmu Pertanian Vol. $6(2): 157-168$.

Kariyasa., Kasryno. 2004. Dinamika pemasaran dan prospek pengembangan ternak sapi di Indonesia. Badan Penelitian dan Pengembangan Pertanian Departemen Pertanian, Jakarta

Kasworo, A., M. Izzati, Kismartini. 2013. Daur Ulang Kotoran Ternak Sebagai Upaya Mndukung Peternakan Sapi Potong Yang Berkelanjutan di Desa Jogonayan Kecamatan Ngablak Kabupaten Magelang. Prosiding Seminar Nasional Pengelolaan Sumberdaya dan Lingkungan 2013 "Optimasi Pengelolaan Sumberdaya Alam dan Lingkungan dalam Mewujudkan Pembangunan Berkelanjutan". Semarang, 10 September 2013. hal. 306-311

Kusnadi, U. 2008. Inovasi Teknologi Peternakan dalam Sistem Integrasi Tanaman-Ternak untuk Menunjang Swasembada Daging Sapi. Pengembangan Inovasi Pertanian 1(3), 2008: 189-205

Priyanti, A., B.M. Sinaga., Y. Syaukat., S.U. Kuntjoro. 2008. Dampak Program Sistem Integrasi Tanaman - Ternak terhadap Pendapatan dan Pengeluaran Petani : Analisis Simulasi Ekonomi Rumah Tangga. Forum Pascasarjana Vol. 31 (4) : 45 - 58

Suryana. 2009. Pengembangan Usaha Ternak Sapi Potong Berorientasi Agribisnis dengan Pola Kemitraan. Jurnal Litbang Pertanian. Vol. 28(1), hal. 29-37.

Syamsu, J. A. 2006. Analisis Potensi Limbah Tanaman Pangan Sebagai Sumber Pakan Ternak Ruminansia di Sulawesi Selatan. Disertasi. Sekolah Pascasarjana Institut Pertanian Bogor, Bogor. 